\title{
Article
}

\section{Two Egyptian Heart-Scarabs from Sicily and a Parallel from Berlin}

\author{
Claude Laroche, Gloria Rosati
}

Two Egyptian heart-scarabs, both connected to the city of Cefalù, are presented here: the first one, at Palermo, Museo Archeologico Regionale, was published in 1942 by E. Bacchi, as one of the few heart-scarabs found outside Egypt, on the rock of Cefalù. Its text has been checked and some new readings are proposed. Inscribed for a Chantress of Bastet, it shows a peculiar decoration on the first register, looking like a lunette, then the traditional beginning of Chapter 30B of the Book of the Dead, typical for heart-scarabs, combined with a rare variant. It had remained a unicum until July 2020, when a parallel in the Berlin Museum came to our knowledge, and this is published here as well: the same decoration in the first register and the same text, although shorter. Mainly on the base of prosopographical data, a date to the Twenty-second Dynasty seems appropriate for the Berlin scarab, and consequently for the one in Palermo, which could even belong to a member of the same family. The owner of the scarab in Berlin shows a set of priestly titles that are typical of Per-Sopdu/Saft el-Henna, which therefore may be an indication of its origin. The second "Sicilian" scar$\mathrm{ab}$, held at Cefalù itself in the collection of Enrico Pirajno Baron of Mandralisca, after whom the Museum is named, is unpublished. Its owner was another Chantress, serving Amun-Re, and nearly contemporary: it is to be dated to the early Third Intermediate Period, Twenty-first - Twenty-second Dynasty. In the Appendix at the end, notes and remarks on the provenance of the two scarabs in Sicily, documenting mainly the discovery of the Palermo scarab.

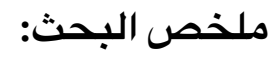

تظهر هنا قطعتــان تمـائم جعـر ان القلب المصـرية، ترتبط كلاهما بمدينة تنتِفالو: القطعة الأولى، معروضة في المتحف الأتثري الإقليمي في مدينةِ باليرمو، نُشِِر عنها في عام 1942 من قبل إ. باكي كاحدى جعر ان القلب الفرعونية النسادرة التي وُجدت خـارج

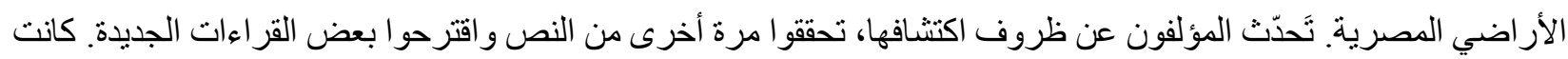

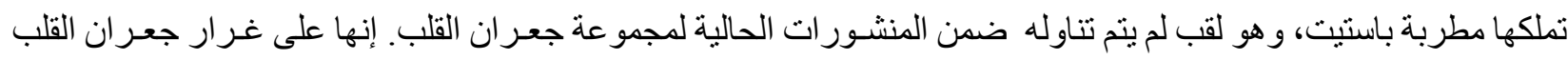

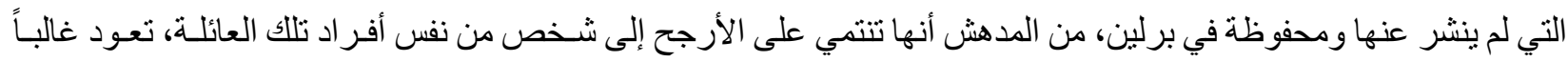

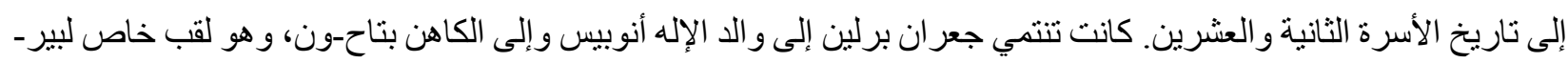

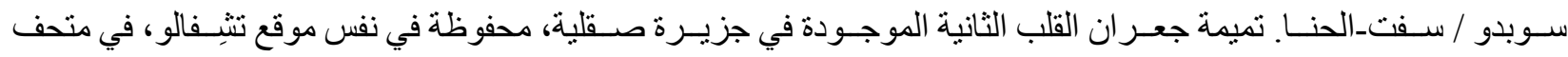

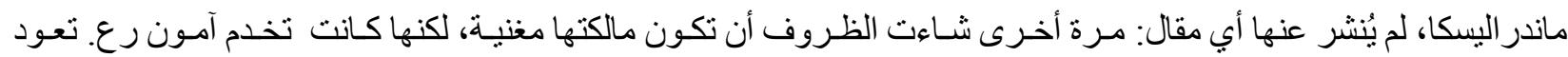
القطعة أيضاً إلى أو ائل فترة الإنتقال الثالثة.

To the memory of Prof. Rosario Ilardo, who would have certainly liked to read these pages.

Two of the heart-scarabs presented here are both connected to the city of Cefalù: one is from Cefalù itself, having been discovered there, and is therefore one of the few specimens found outside of Egypt or Nubia; the other is held in Cefalù. The first one is published, but its text has been checked and a revised version is presented here. The second one is unpublished. When this paper was nearly ready for submission, the authors chanced on a parallel for the first scar$\mathrm{ab}$ in a still unpublished heart-scarab in the Berlin 
Museum. The article has therefore been expanded to include this third specimen, which allowed us to convincingly revise the date we had originally settled on for the scarab discovered in Cefalù.

This article was written by both authors in close cooperation. Gloria Rosati coordinated the work, personally examined the two scarabs in Sicily ${ }^{1}$ and researched their provenance. In the present study, she was mainly concerned with the translation and commentary of the texts. Claude Laroche found the Berlin Museum parallel, wrote the descriptions of the scarabs and was mainly concerned with dating issues, particularly as regards the Berlin scarab.

\section{Museo Archeologico Regionale "Antonino Salinas", Palermo, inv. no. 18405 (Fig. 1)}

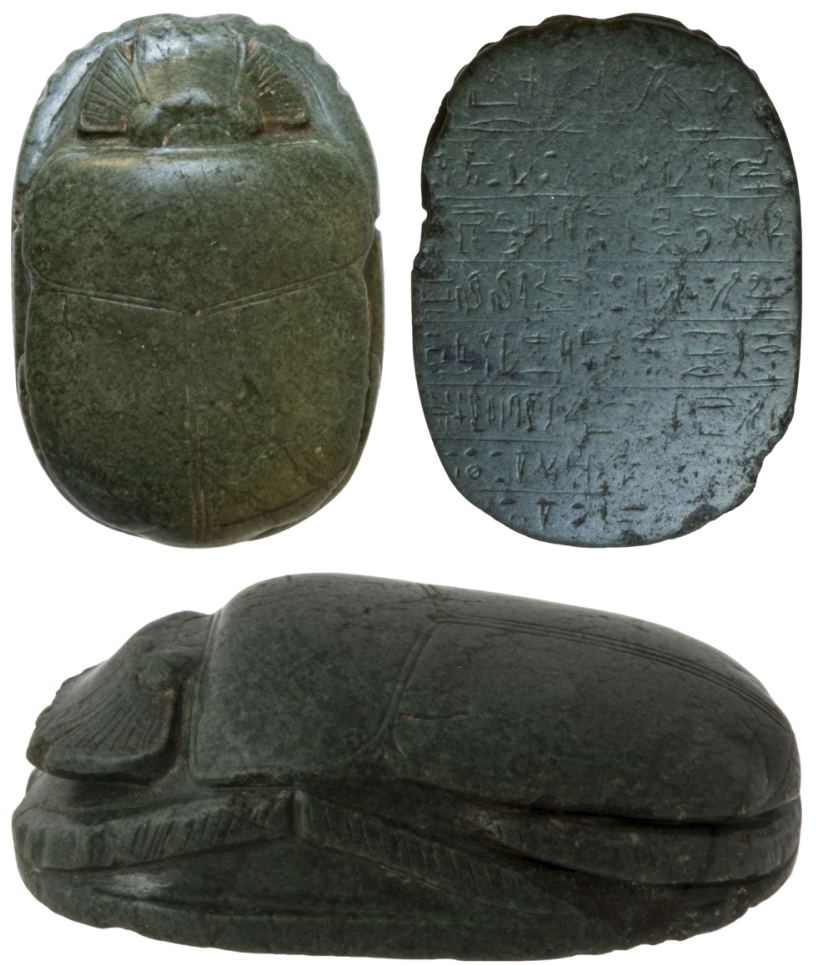

Fig. 1: Scarab, Museo Archeologico Antonino Salinas, Palermo, inv. no. 18405. Photos courtesy of Archivio Fotografico, Museo Salinas.

\subsection{Description}

Dimensions: 71 x 51 x 28 mm; weight: 168.09 g. Material: dark green stone (peridotite ?), ${ }^{2}$ with a thin black vein.
Provenance: found at the end of 1939 or beginning of 1940 on the rock of Cefalù. Reported as a fortuitous find not far away from, but at a lower level than, the so-called Tempio di Diana. ${ }^{3}$

This well-preserved heart-scarab was published, soon after its discovery, by a young collaborator and pupil of Giulio Farina's, Ernesta Bacchi, as an addition at the end of her article concerning a heart-scarab bearing the name of Thutmosis IV in the Turin Museum and reported to come from Sardinia. ${ }^{4}$

Its profile is a subrectangular oval. Its schematic, parallelepiped-shaped legs are separated by grooves of medium depth and decorated with parallel lines. The clypeus, which would have had several indentations, is damaged and now shows only one. The cheeks are decorated with striations and the elytra with two notches in the shape of a shield. It seems that the prothorax is decorated by a half circle that we call a "circular crown", which however is barely visible. The suture between the prothorax and the elytra is represented by a double line engraved in a shape between $\mathrm{U}$ and $\mathrm{V}$, and the one separating the elytra by three parallel lines extended at the rear end of the scarab by small concentric triangles.

On the base - a small part of whose edge is chipped - a text is engraved in seven lines and a lunette at the top, which contains the image of Anubis as a recumbent jackal. Because of the representation of this god and the content of the text, which combines the beginning of Chapter 30B of the Book of the Dead and an uncommon variant, this scarab appeared as a unicum in a corpus of the 1600 heart amulets inventoried in $128 \mathrm{mu}-$ seums and private collections by one of the authors of the present article, ${ }^{5}$ until an unpublished parallel was discovered in July 2020, as explained below.

In spite of its near uniqueness and peculiar circumstances of discovery, there seems to be no reason to doubt the authenticity of the object. It is a scarab of beautiful workmanship, and well-preserved, notwithstanding the chipping of the clypeus and the edge of the base, and the wear of the text. It has a parallel in the above-mentioned heart-scarab bearing the name of Thutmosis IV, in Turin, ${ }^{6}$ which, oddly enough, was also reported to come from outside Egypt, having been found at Tharros in Sardinia. ${ }^{7}$ Bacchi indicated as a parallel another Turin scarab, 
C. $5993,{ }^{8}$ dating from the Amarna period: this one, however, has three incised lines between the prothorax and the elytra instead of two, and different legs; it can thus hardly be regarded as a close parallel. The use of green stone, two or three suture lines, and slightly hatched schematic legs are all features found on many scarabs and are not chronologically distinctive. More interesting is the hatching of the cheeks, which has parallels mostly - although not exclusively - in the New Kingdom. ${ }^{9}$

\subsection{The inscription}

Ernesta Bacchi was probably able to read the inscription on the scarab's base working from photographs only, or casts. Indeed, photos of it were taken soon after its discovery, and molds made, both with sealing-wax and plaster. For some reason, perhaps technical ones, her transcription, however, is here and there more of a mere transcription than a true copy of the inscription; in particular, the position of a few signs is different than on the original.

The hieroglyphic inscription is very lightly incised, as well as worn and chipped along the edge. Nevertheless, it is illegible only in a few places.

The text (Fig. 2) consists of seven lines and a sort of small lunette on top, an unusual feature indeed. It

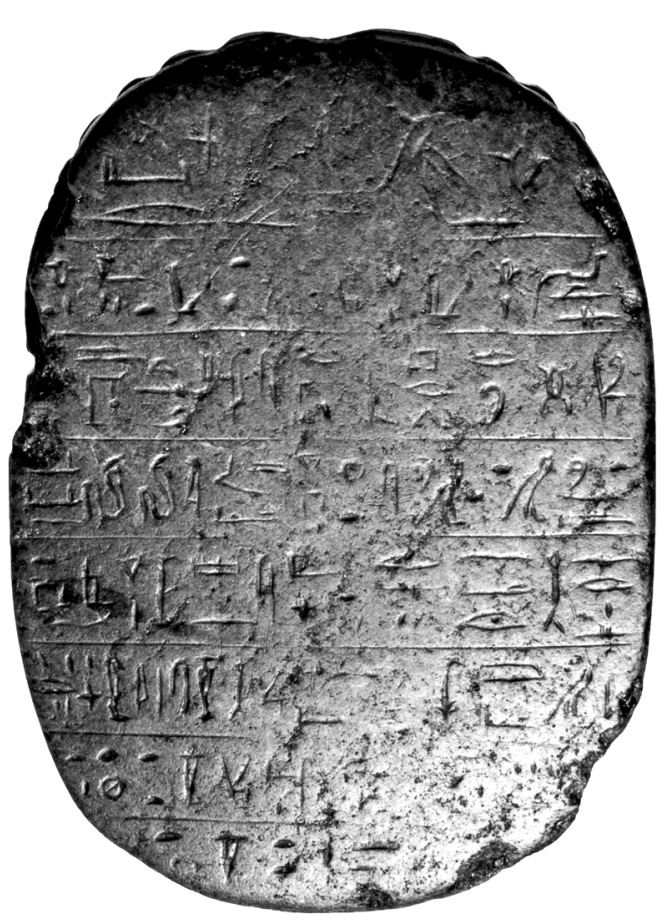

Fig. 2: Scarab, Museo Archeologico Antonino Salinas, Palermo, inv. no. 18405 - base. Photo courtesy of Archivio Fotografico, Museo Salinas. Processed by Alessio Corsi. is interesting to mention that one of the two heart scarabs belonging to Osorkon II from the Twenty-second Dynasty, kept at the Brooklyn Museum, ${ }^{10}$ is, besides this one (and its Berlin parallel, discussed below), the only heart scarab in the corpus so far collected ${ }^{11}$ to be decorated in the first register (the goddess Maat, a phoenix and a fan). One could also mention, for comparison's sake, the "layout" of the text inscribed in an oval inserted in a pectoral, above a winged scarab, ${ }^{12}$ but this text is not a regular heart-chapter text. There in the lunette on top, two winged snakes flank the akhet-sign, then six inscribed lines follow, with the owner's name, the beginning of a hetep-di-nesu-formula on his behalf, and at the end some words probably recalling the beginning of Chapter BD 30B.

Anubis as a recumbent jackal is in the middle of the lunette, looking right, with a band tied around his neck; in front of the god, the figure of a heart; above and behind the god, the hieroglyphic caption:

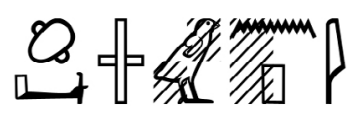

$\operatorname{inp}[w] \operatorname{im}(y)-w t$

"Anubis, who is in the embalming-placea".

${ }^{\text {a }}$ In the Wörterbuch, the determinative of $w t$, forearm with stick (Gardiner D40), is indicated as being mainly a New Kingdom feature: Wb I 378,9 (verb), 380,10 (name), 380,3 (in imy-wt).

The heart is a little larger than the other hieroglyphic signs and is not a part of the caption: it is certainly the image of the owner's heart in front of Anubis, the god in charge of the weighing. ${ }^{13}$ Bacchi did not copy the sign, although it is quite clear; in a cast, however, it could have looked like a chipped place.

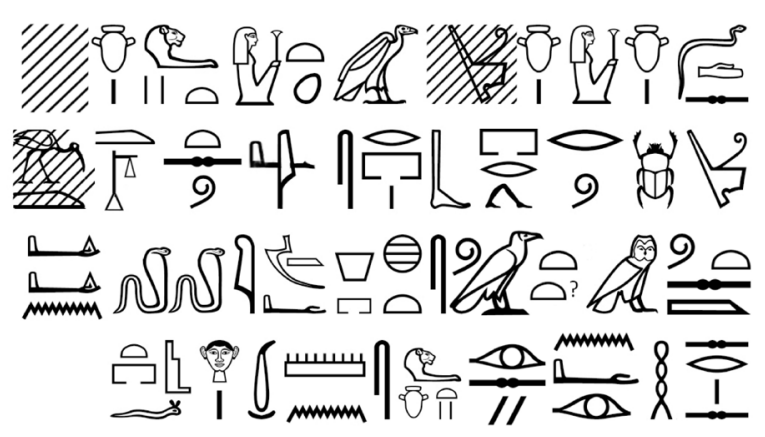




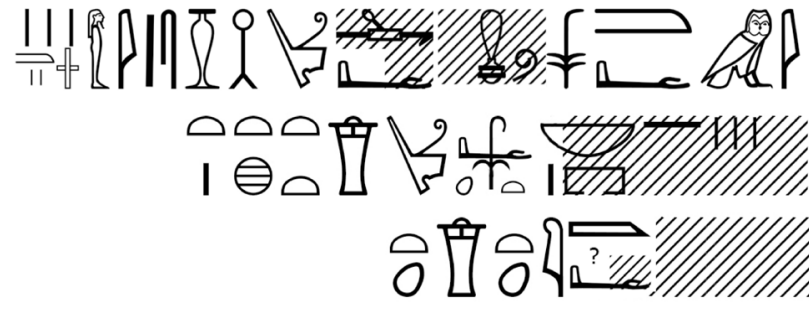

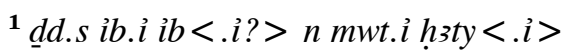

${ }^{2} n$ hprw $<. \grave{l}>\operatorname{pr} r b(w)<n f r>\operatorname{sip} . t w . s m$ mh3t $[g] m$

${ }^{3}$.tw.s $(m) m 3^{e}(t) m\{t\} t 3$ wsht $m 3^{e} t y d d n$.

${ }^{4}$ s rz.s ḥn irty.sy ḥзty.s mn(.w) ḥr st.f

5 im $s w$ mỉ we $n$ hsyw imy[w]

${ }^{6}$...w...n...nb(t)-pr šm $m^{\top} y t$ n b3stt tht

${ }^{7}[\ldots] m 3^{e} t-b 3 s t t$

"She says": "My $i b$-heart, (my?b) ib-heart of my motherc, (my) haty-heart $\left.\right|^{2}$ of (my) transformations, come to the $<$ Beautiful $>$ Place ${ }^{\text {d! }}$ " She shall be examined ${ }^{\mathbf{e}}$ on the scales ${ }^{\mathrm{f}}$ and she shall be found $\left.\right|^{\mathbf{3}}$ right $^{\mathrm{h}}$ in the Hall of the Double Justice. Her $\left.\right|^{4}$ mouth shall be given back to her together with her eyes, her heart (haty) being firm in its place. $\left.\right|^{\mathbf{5}}$ Take him (sic) as one of the praised ones ${ }^{\mathbf{j}}$ who are $\left.\right|^{\mathbf{6}}$ [following you (?), (namely)] the Lady of the House, Chantress of Bastet ${ }^{\mathbf{k}}$, Tekhet $1^{7}$ [whom] Maat-Bastet ${ }^{\mathrm{m}}$ [has made] (or [daughter of (?)] Maat-Bastet $\left.{ }^{\mathrm{m}}\right)$ ".

a The text begins directly with the speech of the owner, whose name is written only at the end of the text. $^{14}$

b There seems to be not enough room for two signs, as in Bacchi's copy: only an oblique vertical stroke survives, and it looks more like a Red Crown sign for $n$ (cf. beginning of next line, Gardiner S3) than a sitting woman. The use of this sign is an important dating clue, because it is not witnessed on heart-scarabs before the reign of Tutankhamon ${ }^{15}$ and, although it is known in the Late Period, too, it is more frequent from the late Eighteenth to the Twenty-second Dynasties. At the end of the line, too, room does not seem enough for another sitting woman sign, and the incision resembling a $t$-sign is more probably a deep scratch.

' Ch. BD 30B usually begins with these words, to be repeated twice ( $s p 2)$; the absence of $s p 2$ and the repetition of $i b . l$ is to be noted. A "traditional" translation is of course kept here. ${ }^{16}$

d This wording differs from the usual text of the chap- ter and remained unique among heart-scarabs until recently. Bacchi, having no parallel, understood: $p r$ $<r>b(n) r^{17}$ and translated as a participle to be referred to the heart: "come out (scil. from the mother's womb)". M. Malaise, ${ }^{18}$ based on her transcription, translated in a more appropriate way: "puisses-tu sortir vers l'extérieur (c'est-à-dire quitter la tombe pour atteindre le lieu du jugement)". The sequence of signs in $b(n) r+$ det. of house + stroke is sufficiently correct and does not suggest oversights or mistakes, apart from the lack of the initial preposition $r$. On the contrary, on the base of the parallel in Berlin (see below), we have to admit another missing term here and consequently a different reading: not $\langle r\rangle$ $b(n) r$, but $r$ (misplaced) $b(w)$ (stroke written under instead of above the $p r$-sign) $<n f r\rangle$, that is "come out to the <Beautiful> Place", where the judgement will take place. As the figure of the heart at the top may suggest, the heart is described in some texts as "another self"; ${ }^{19}$ the very fact that it could act against its owner is proof of its independence, and many vignettes show its owner adoring it as an independent entity. The owner, on the other hand, is sometimes shown proceeding to the final judgement with his heart on his hand, in his "possession".

e The following signs, after an initial $s$, are puzzling, because they are definitely an $i$-reed (Gardiner M17) with another sign behind it, looking like the e-forearm (Gardiner D36). Bacchi - and Malaise, following her - found the solution to consider the reed a mistake for the mast (Gardiner P6), often found intersected by the -forearm. They thus both read: se $h$. $t w . s m$ h $h w t$, and translate: "May she be raised from the grave" $\left(\mathrm{Bacchi}^{20}\right)$; “afin qu'elle soit élevée (?) dans le temple (?)" (Malaise). The problem now is that the $h w t$-sign cannot be maintained (see below, note $\mathbf{f}$ ), and when referring to a judgement the verb $s^{c} h^{c}$ means "to accuse" (Wb IV 54,4), exactly what the heart is implored not to do. Instead of $s$ he, the only alternative is the verb usually found for "to examine", sip (Wb IV 35,11), and now the Berlin parallel text discussed below confirms our suggested reading: the signs $s$ and $i$ are certain; the reed sign is not crossed by the forearm, which is very lightly engraved, and the hand cannot be seen and seems indeed not to have been carved. On the contrary, the arm and elbow part is more deeply engraved and 
has a rather marked rectangular shape. In fact, this part is notably larger than, e.g., in the sign on the next line. It is not impossible that in this place the engraver tried to correct, or write better, something that might actually be a $p$-sign (Gardiner Q3). The proposed transliteration is, therefore, sip.tw.s, with an inversion of the last two signs.

f This sign was not correctly recognized by E. Bacchi, who transcribed it as $h w t$ (Gardiner O6). On the contrary, the sign (whose normalized JSesh transcription above only roughly reproduces) does not have a closed form and is certainly a balance with its post and a single scale-pan, a sign which is seldom found instead of the regular ideogram for mh3t (Gardiner U38). ${ }^{21}$ Eighteen examples are nevertheless known in the corpus of heart-scarabs, ${ }^{22}$ showing single scale-pan balance signs of various types, which are recorded in the French National Library catalogue of hieroglyphs. ${ }^{23}$ It is worth noting that it is probably found on two of the oldest heart-scarabs - with human heads - dating from the Thirteenth Dynasty. ${ }^{24}$ Moreover, it is confirmed by the parallel text on the Berlin scarab.

${ }^{\mathbf{g}}$ At the end of the line only a few traces survive: below, probably a part of an $m$, Gardiner Aa13. Above it, outside the chipped part, an oblique and slightly curved segment: it is very similar to the beak of the gm-bird, Gardiner G28.

${ }^{\text {h }}$ At the beginning of line 3, after $t w . s$, is a very low sign, possibly closed by the stroke on the left, hence read here as Gardiner Aa11, $m_{3}{ }^{c}$, confirmed by the Berlin parallel. Then two small signs between two birds (both $m$-owls in Bacchi's copy), above certainly $t$, below likely a second $t$, partly chipped and thus similar to a $k$. Is this the sign read as $s \underline{d m}$ (Gardiner F21) by Bacchi? If so, her reading is very unlikely. On the basis of the parallel text, we suggest that the second bird, which shows a slightly different tail from the first one - which is certainly an owl -, a straighter back but no beak, ${ }^{25}$ might be instead the 3 -vulture, so that we would have here, too, $t 3$ wsht, "the Hall". One of the preceding small signs, the first $t$, seems unnecessary, unless it is to be connected as a female ending to $m_{3}{ }^{r}$, and misplaced.

'After the $s w$-sign, probably a tiny trace of the complementing $w$. The masculine pronoun, instead of the feminine, is a frequently found swap. In this inscription it is the only one, the agreements being correct elsewhere. As for $m i$, it is barely visible but sure, and there seems to be enough room after it even for a $i$-sign, which however would then be completely lost.

$j$ The first $l$ is "reduced" to a vertical segment.

${ }^{k}$ S.L. Onstine ${ }^{26}$ has devoted a monograph to the feminine title šm ${ }^{\prime} y t$ or Chantress, which occurs from the Middle Kingdom onward and is associated with the state religious hierarchy. Onstine includes in her database 861 women holding this title. 589 are classified as New Kingdom and 252 as Third Intermediate Period. Among the latter, 206 could be attributed to the Twenty-first Dynasty, of which 34 are dated to the late Twenty-first - early Twenty-second Dynasty span of time; only 28 references are given for the subsequent time span, which is all in the Twenty-second Dynasty. ${ }^{27}$ As for the New Kingdom, the peak of occurrences is from the Nineteenth Dynasty (Eighteenth Dynasty: 103; Nineteenth Dynasty: 274; Twentieth Dynasty: 85; Nineteenth or Twentieth Dynasty: 61; New Kingdom: $23^{28}$ ). When we look for Chantresses of the goddess Bastet in the book, however, we find very few (in Onstine's Appendix $\mathrm{E}^{29}$ ):

- nos. 38-39 and 41-43 (the same family), Nineteenth Dynasty, Merenptah;

- no. 412, New Kingdom;

- no. 492, Eighteenth Dynasty, Amenhotep III, from Bubastis;

- no. 515, Eighteenth Dynasty;

- no. 651, New Kingdom, from Bubastis;

- no. 652, Eighteenth Dynasty, Amenhotep III, from Bubastis;

- nos. 721-722, Nineteenth Dynasty, Merenptah, from Thebes;

- no. 877, Nineteenth Dynasty, Ramesses II, from Thebes;

- no. 929, Nineteenth Dynasty, Ramesses II, from Saqqara.

Another one, to be added to the above list, is a šm $y t$ $n(t) b$ sstt $n f r$ or $n f r(t)$ from Saqqara, attributed to the Nineteenth Dynasty. ${ }^{30}$

' If indeed the name is complete: cf. Ranke, PN I 382, 29-31; I 383, 2-3, with references mainly from the Middle Kingdom and New Kingdom; and cf. Wb V 324, "die Trunkenheit"; or probably thyt, "Belonging to the month Tekhy"? (Wb V 325, 18). At the begin- 
ning of the next line there is room enough for about two squares before the two visible horizontal signs: there at least the presence of an expression of filiation is expected.

${ }^{\mathrm{m}}$ Not recorded in Ranke, $P N$; cf. Ranke, $P N$ I 144 , 26 (m3't-pth, m.); I 145, 1 (m3't-m-dhwty, f.); I 145, 5

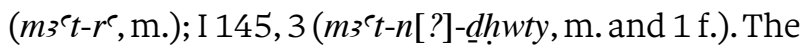
signs are very worn and unclear at the beginning of the line; then the $n b$-sign in Bacchi's transcription (reading $n b t-p r$ ) is unlikely, and almost certainly a $m_{3}{ }^{c}$, Gardiner Aa11; the long and thin sign underneath matches the - -forearm (D36; whereas an oar $h r w(\mathrm{P} 8)$ is unlikely, if one were to think of a reading

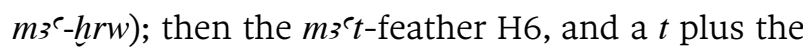
egg (H8).

The text inscribed on the Palermo scarab shows the traditional beginning of BD Ch. 30B. Then it introduces a variant, the sentences uttered by the gods who witness the weighing of the heart at the end of this chapter. ${ }^{31}$

A selection of those sentences is gathered by Seeber. $^{32}$ Bacchi found a very similar wording on a coffin in Marseille (Table 1), dating however from the Twenty-first Dynasty ${ }^{33}$ and with a considerably longer and more structured text (translation by G. Maspero):
"Voici N dans cette salle de la double Vérité, et, à estimer son cour ainsi qu'à le peser $[\grave{a}]^{34}$ la balance devant les grands jurés $d u$ maître de l'Hadès, il a été trouvé vrai, on n'a trouvé aucune impureté terrestre en son cour ; maintenant qu'il sort ${ }^{35}$ juste de voix (triomphant) du Prétoire de l'Hadès, son cour lui est rendu avec son oil, son cœur matériel est à la place [ou il était] de son temps [terrestre], son âme va au ciel, son corps à l'Hadès, comme pour les suivants d'Horus. Donne [donc] son corps aux bras d'Anubis, le maître du tombeau ${ }^{36}$, donne-lui des offrandes au cimetière en présence d'Ounnofri, donne qu'il soit comme un de ces loués qui sont derrière toi; donne que son âme s'établisse en tout lieu qu'il lui plaira à l'Occident de Thèbes".

Based on stylistic criteria, on paleographic details, and on the frequency of the owner's title, we would consider for the dating of this scarab a period of time from the Nineteenth to the Twenty-second Dynasty; however, while at first the New Kingdom seemed a suitable and convincing proposal, the discovery of a parallel has come to suggest otherwise. In July 2020, Claude Laroche received from the Berlin Museum a number of photographs of unpublished heart-scar-

Marseille inv. 253/1

Scarab

$m k \mathrm{~N} m$ wsht misty $r h n^{\complement} \underline{\sin i b . f(m) m h 3 t}$ m-b3h $\underline{d}_{3} \underline{d}_{3} \mathrm{C}^{\mathrm{C}} 3 \mathrm{t}$ nbt dw3t $\underline{\mathrm{sw} \text { gm.tw } \mathrm{m} \mathrm{m}_{3} \mathrm{~m}^{\mathrm{C}}}$

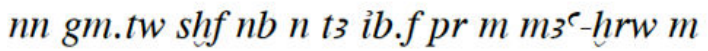
wsht hrt-nter $\underline{d d n \text {.fib.f } r h n^{\circ} i r t . f h 3 t v . f r}$ st tr.f b3.fr pt hist.f $r d w 3 t$ mi šmsww -hrr im hist.f cwy inpw imy hnt pr nfr im n.f htpt $m$ r $r 3-s t 3 w$ $m-/ b 3 h /$ wnn-/nfr $\underline{i m s(w) / m i} w^{\top} n / n z \quad h s v / w n t v i m y-h t . k$ im iry $b_{3} . f b(w)-n b \quad n$ mr. fimy wrt $n$ w3st sip.tw.s $m m^{m} 3 t$

[g]m.tw.s (m) $m 3^{e}(t) m\{t\}$ to wsht misty

dd n.s r3.s ḥn irty.sy ḥsty.s

$m n(. w)$ ḥr st.f

im sw mỉ we $n$ h hsyw imy $[w \ldots$ 
abs to be included in the corpus he is preparing for publication. Among them, one surprisingly turned out to be a parallel for both the decoration and the text of the Palermo scarab.

\section{Berlin Ägyptisches Museum und Papyrussammlung, inv. no. ÄM 34343}

(Fig. 3)

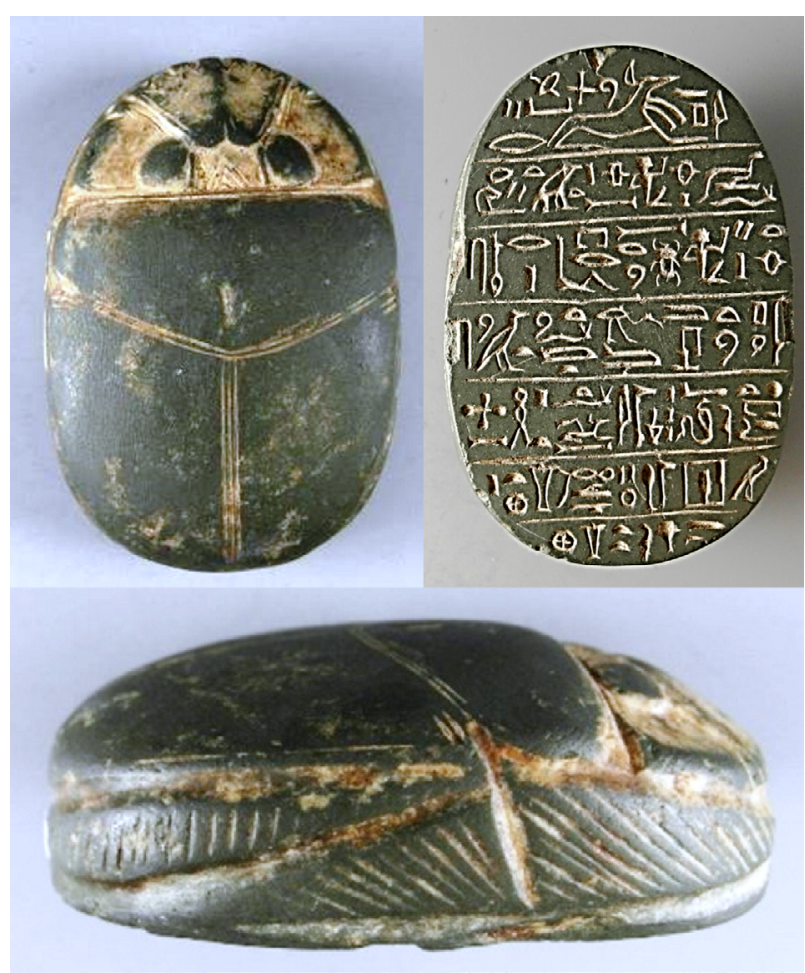

Fig. 3: Heart scarab Berlin, inv. no. ÄM 34343.

๑Staatliche Museen zu Berlin, Ägyptisches Museum und Papyrussammlung, photos by Frank Marohn.

\subsection{Description}

Dimensions: 56 × 38 x 20 mm; weight 78 g. Material: dark green greywacke.

Provenance: not recorded; former Georges Michaelides collection, acquired by the Berlin Museum in $1973 .^{37}$

This dark green scarab is of medium size, much smaller than the scarab at Palermo, and almost perfectly oval. The prothorax is separated from the elytra by a double U-shaped suture line, while the elytra themselves, which have no notches, are separated by a triple line. The clypeus with five indentations is framed by two large ovoid eyes, between which is engraved a pattern of three equilateral triangles nested within each other, which we have called a "triangular crown". The sides of the scarab are cut by shallow grooves into three triangles decorated with hatching, representing the so-called type 2 legs (in Laroche's terminology), while the hatched legs of the Palermo scarab, separated by deep grooves, belong to type $1 .^{38}$ The base is inscribed similarly to the Palermo scarab, with a text arranged in a lunette and six lines. Here, too, the lunette shows Anubis as a recumbent jackal. Then come the first two canonical lines of Chapter 30B, followed by the same peculiar variant, although a little shorter, as seen above. The text is concluded by the titles and name of the owner, Shedsubastet, as well as, probably, the name of one of his parents, Maat-Bastet.

\subsection{The text}

The lunette only shows Anubis, and not the heart in front of the god as on the Palermo scarab. The figure's caption fills the space in front of and above it.

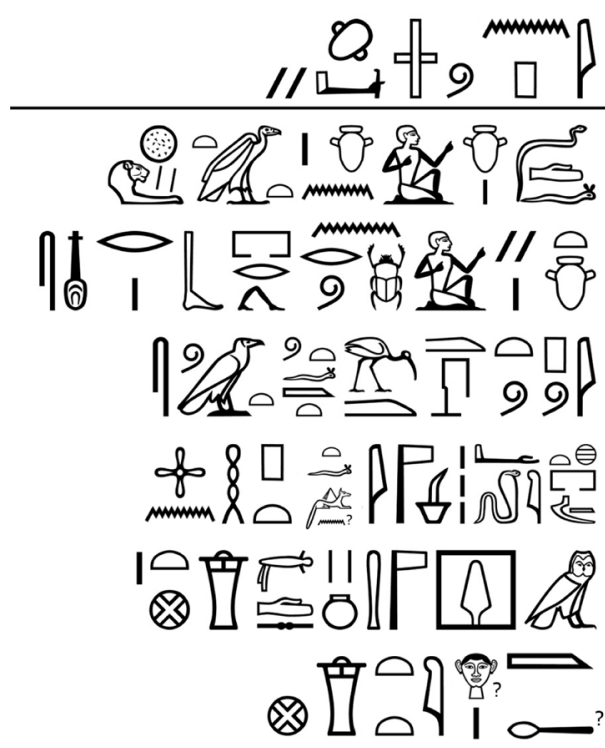

inpw imy-wt

"Anubis, who is in the embalming-place ${ }^{\mathrm{a} "}$

a The writing of $i m y-w t$, with two strokes at the end, is rather suitable for a post-New Kingdom date ( $\mathrm{Wb}$ I 378-80).

Only three-and-a-half lines contain the beginning of BD Ch. 30B and the first phrases of the "variant", then the titles and name of the owner. The text be- 
BERLIN ÄM 34343

$\underline{d d}$.f $i b . i \overrightarrow{i b}<. i>n m w t<. i>s p 2 h \underline{h}=$

ty.i $n$ hprw<.i $>$ pr $r b(w) n f r \quad s=$

ip.tw<.f> m mhst gm.tw. $f(m) m_{3}{ }^{e}\{t\}<m>$

t3 $w s=$

ht $m 3^{\complement} t(y)\{w\}$ it-ntr hrry sštz ptḥ-wn

$m$ ḥwt-nbs hmm-ntrr 2-nw šd-s(w)-b3st(t)
PALERMO 18405

dd.s ib.i i $i b<. i>n$ mwt.ỉ $h 3$ ty $<. i>$

$n$ hprw $<. i>\operatorname{pr} r b(w)<n f r>$

sip.tw.s $m$ mhst $[g]$ m.tw.s $(m) m_{3^{c}}(t) m\{t\}$ tz

wsht misty

$m_{3}{ }^{e}-h r w\left(\right.$ ?) $s 3$ (?) $m_{3}{ }^{e} t-b 3 s t t$

Table 2

gins exactly as on the Palermo specimen, directly with the speech of the owner (Table 2).

"He says: - My $i b$-heart, (my) $i b$-heart of (my) mother - two times -, my haty-heart of (my) transformations $s^{\mathrm{a}}$ Come out to the Beautiful Place ${ }^{\mathrm{b}},-<\mathrm{He}>$ shall be examined on the scales and he shall be found right <in> the Hall of the Double Justicec, (namely) the God's Father, Master of Secrets, pth-wn-Priest in the Mansion of the Jujubed, Second Prophet Shedsubastet ${ }^{\mathbf{e}}$, justified (?), son of (?) Maat-Bastet"

a The presence or absence of suffix pronouns is nearly analogous in the two versions, but the "repetition" (sp 2) is not omitted here. The $n$-sign is not, this time, the chronologically relevant Red Crown (Gardiner S3, see above).

b Here the presence of $n f r$ is clear; the reading is therefore beyond doubt $b w-n f r$, which is the place of judgement. ${ }^{39}$ The $r$-sign is misplaced after $b(w)$, in what is otherwise a well-known writing of the term (Wb I 450). In the Palermo scarab, a pr-sign is added as a determinative.

c The plural is clear in the Berlin version, an unusual writing instead of $m_{3}{ }^{c} t y$, perhaps influenced by writings of $m^{c} t$ (Wb II 18-19); or probably by expressions such as, e.g., t3 $n m^{c} t y w, W b$ II 21, 10. For a parallel, cf. the writing $m_{3}{ }^{\mathrm{C}} \mathrm{t} y+$ plural on a dummy canopic jar in Munich. ${ }^{40}$

d The owner of this scarab shows a set of interesting priestly titles, known to us mainly for the Late
Period so far. This is the case of the still rather rare pth-wn, "creator of light" as proposed by Yoyotte, ${ }^{41}$ and listed as the Priest of Per-Sopdu (20 ${ }^{\text {th }}$ Lower Egyptian province) in the Great Geographical List at Edfu; ${ }^{42}$ indeed, the title is completed with the mention of Hut-nebes ("Mansion of the Jujube"), a very holy place there, a name for the sanctuary and for the town. ${ }^{43}$ Its presence is an important chronological clue, as it is known so far certainly since the Twenty-second Dynasty. ${ }^{44}$ As for "Master of Secrets", in the cryptic writing known since the Middle Kingdom, ${ }^{45}$ it is attested together with pth-wn in the sequence of titles on an anonymous block-statue. ${ }^{46}$

e Shedsubastet is listed in Ranke, $P N$ (I 331, 6; II, 391) as Late Period, but the name-form is earlier: cf. the examples with Amon, Mut, Khonsu (PN I 331, 5, $7,11)$ from the New Kingdom.

f The signs in the last line are not at all clear, but the first one is very probably a $m_{3}{ }^{c}$ (cf. 1. 5), so that a $m^{c}$-hrw could be very likely, although the horizontal sign beneath is not convincing either as an e-sign or as a hrw (Gardiner P8), and the latter does not even match the following vertical sign(s?). As to these, what we would expect here is an expression for "son of", because after that we have $m_{3}{ }^{2} t$ - $b 3 s t t$, which is certainly a personal name and the exact same one that was previously only known from Tekhet's scar$a b{ }^{47}$ For the moment, noting that a reading ir.n seems unlikely as well, based on many occurrences (first and foremost in the corpus of heart-scarabs), we can only suggest that the following vertical sign 
could actually be 2 signs: ${ }^{48}$ a $h r$ (D2) written by mistake instead of $s 3$, the egg (H8), and, below it, the stroke (Z1). ${ }^{49}$

\subsection{Dating the Berlin scarab}

The dating of heart scarabs, as Laroche argues, ${ }^{50} \mathrm{de}-$ pends on about twenty plastic and epigraphic criteria, half of which relating to the text of Chapter 30B. None of these criteria are in themselves failproof evidence for a particular period, but they indicate a prevalence of a feature which also occurs over a wider span of time. Only the cooccurrence of several elements prevailing during the same period allow us to propose a date.

As for the Berlin scarab, its shape is comparable to that of a scarab coming from a rather well-dated archaeological context. The excavations of the Spanish mission in the Third Intermediate Period necropolis at Herakleopolis Magna, which at that time was governed by Libyans, ${ }^{51}$ brought to light five heart-scarabs inscribed with a few lines from the beginning of Chapter 30 B. In Fig. 4, the Berlin scarab of Shedsubastet is compared with one of these scarabs, i.e., that of an individual named Kehshasha, ${ }^{52}$ presently held in the museum of Cordoba. There is an evident plastic and graphic similarity between these two scarabs with hatched legs, designated “type 2 " by Laroche. In addition, it is interesting to remark that the scarab of Kehshasha, too, is inscribed with the beginning of Chapter 30B followed by a different variant, exactly like some others of the five Herakleopolitan scarabs.

Moreover, we have already pointed out above that one of the two heart scarabs of Osorkon II of the Twenty-second Dynasty, held in the Brooklyn Museum,,$^{53}$ shows a peculiar decoration in the first register. It consists of large motifs occupying almost half the surface of the scarab, representing the goddess Maat, a phoenix and a fan. Like this royal one, our two scarabs in Palermo and Berlin show a large representation of Anubis in the first register. So far, we have found no other parallel for this feature.

In addition to these stylistic features, the owner's titles are important dating clues: as we have seen, neither the title pth-wn nor the toponym $h w t-n b s$ are attested so far before the Twenty-second Dynasty. So, although some features would tend to push the

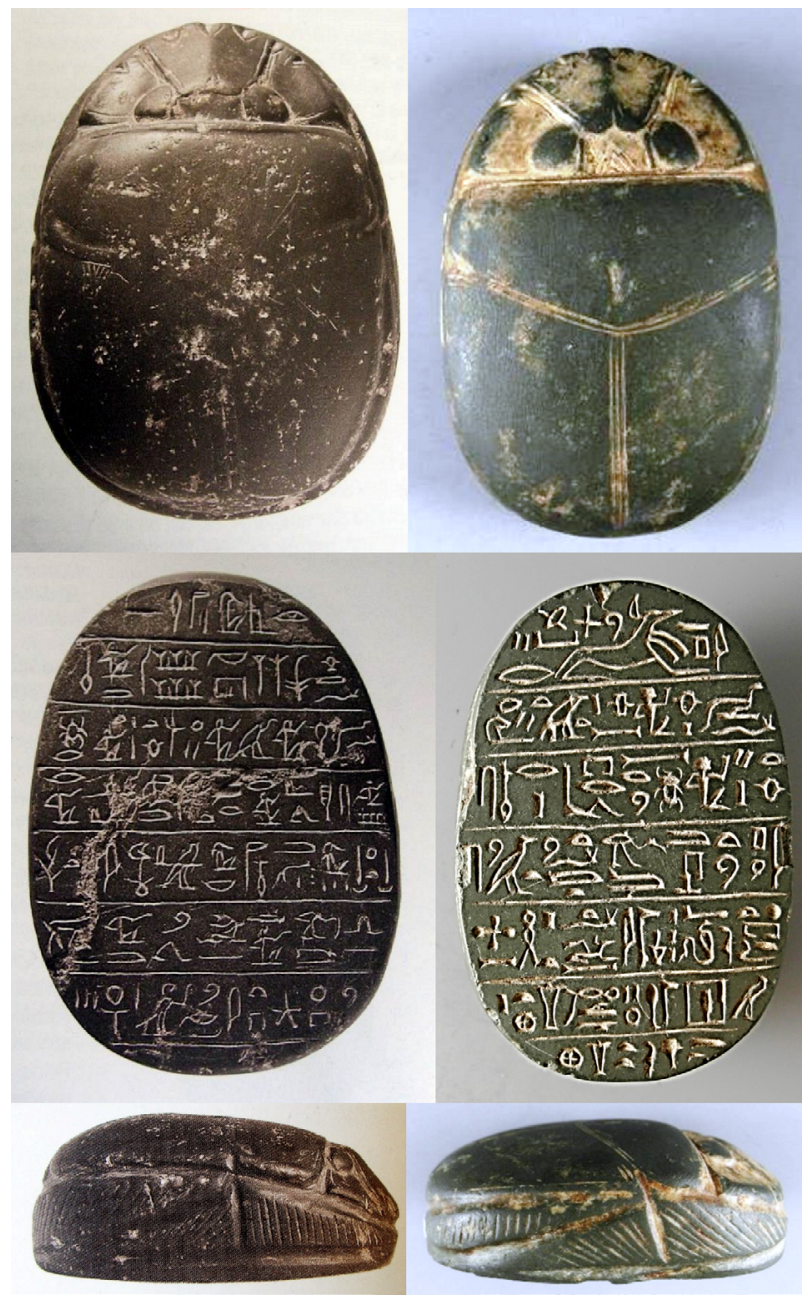

Fig. 4: Left: heart scarab Real Academia de Cordoba, inv. no. 1981/1/102. Photos $\odot$ Real Academia de Cordoba; from: E. Pons Mellado (ed.), La colección egipcia de la Real Academia de Córdoba, Córdoba 1998, p. 69 (photo of the side reversed). Right: Berlin, inv. no. ÄM 34343. @Staatliche Museen zu Berlin, Ägyptisches Museum und Papyrussammlung, photos by Frank Marohn.

date further back in time (such as the number of suture lines $2 / 3$, which is rather characteristic of the Ramesside period, but does occur even subsequently, according to Laroche's research), the other arguments seem much stronger and an attribution to the Twenty-second Dynasty more likely.

\subsection{Using the Berlin scarab for dating the Palermo one}

The Berlin heart-scarab of Shedsubastet, therefore, is to be dated very probably to the Twenty-second Dynasty. It shares a number of features with the Palermo scarab, whose plastic characteristics would seem a priori to be rather from the New Kingdom. They are the only heart-scarabs known so far with the same figuration in the first register or lunette (with the sin- 
gle difference that in the smaller Berlin scarab there is no heart in front of Anubis), and the same text - albeit longer in the Palermo scarab's version - including the traditional beginning of BD Ch. 30B, the exhortation to the heart to come out to the judgment hall, and phrases from the gods' speeches completing the same chapter, known from papyri and other funerary equipment. Both also share the hieroglyphic sign of the half-scales, less common than its full equivalent. It cannot be ruled out that a particular pattern may be revived centuries later; however, the contemporaneity of these scarabs is further borne out by prosopographic evidence. The Chantress Tekhet (provided the name is complete) has a parent whose name is Maat-Bastet: Bacchi read "Lady of the House" before it, but Rosati's check on the original makes it unlikely (see above). Nonetheless, an expression of filiation is expected there (now abraded), be it to introduce the mother's or the father's name. We find the same situation in the last line of the Berlin scarab, where MaatBaste $(\mathrm{t})$ is very clear and could only be introduced by an expression of filiation, which we are unable to read with certainty.

It seems very probable that they belonged at least to the same family, as they were, moreover, both connected to the cults of Bubastis (although Bastet is worshiped throughout Egypt) and Per-Sopdu, less than $8 \mathrm{~km}$ away.

Therefore, we suggest for the Palermo scarab, too, a date to the Libyan Period (ca. 910-720 BC).

\section{Mandralisca Museum, Cefalù, inv. no. $\mathbf{5 2 0}$ (Fig. 5)}

\subsection{Description}

Dimensions: 47 x 28 x 16 mm; weight: $44 \mathrm{~g}$.

Material: yellow-brown steatite, with traces of red pigment.

Provenance: not recorded; collection of Enrico Pirajno Baron of Mandralisca (Cefalù, 1809-1864). ${ }^{54}$

The oval-shaped scarab has schematic rectangular parallelepiped-shaped legs, decorated with a few roughly parallel lines separated by grooves of medium depth. The clypeus has four triangular indentations, one of which is chipped. The suture between
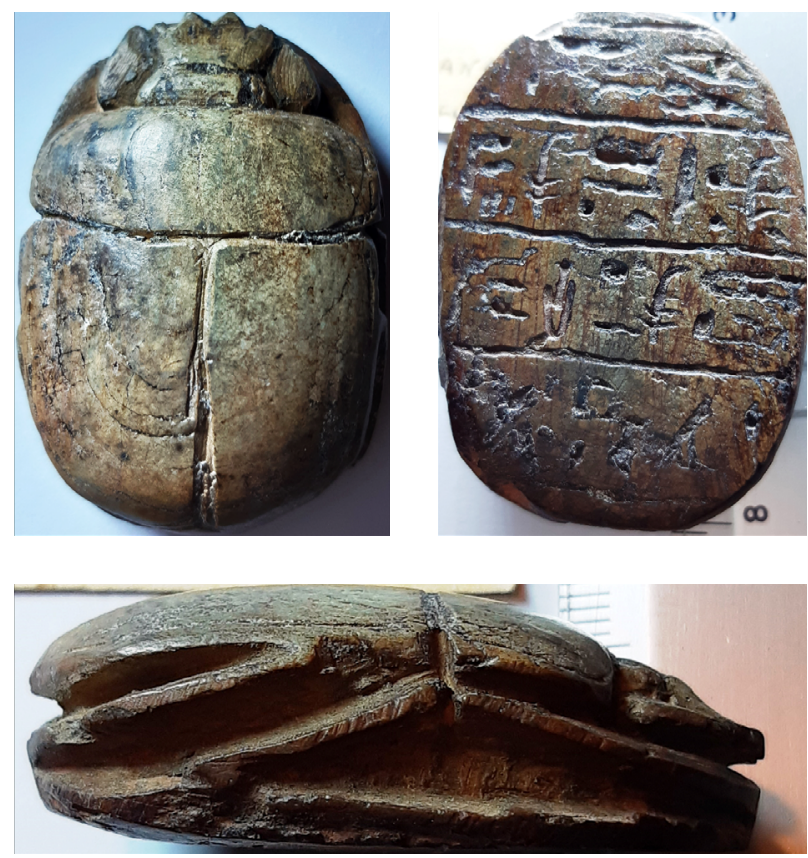

Fig. 5: Mandralisca Museum, Cefalù, inv. no. 520. Photos by Gloria Rosati, published by permission of Fondazione Mandralisca, Cefalù.

the prothorax and the elytra, not decorated with notches, is rendered by a horizontal line and the suture between the elytra by a vertical line, which the sculptor has obviously made several attempts to draw. The lines form a very small triangle at their meeting point.

Inscribed on the base are the name and titles of the owner followed by the beginning of the first sentence of Chapter 30B of the Book of the Dead. The text is contained in four registers divided by hesitant, awkwardly drawn lines. The hieroglyphs were formerly colored with a red pigment which has weathered into brown but for a dot. ${ }^{55}$

\subsection{Text on the base}

On four lines, a hieroglyphic inscription that gives only the owner's name and titles and a very short beginning of BD Ch. 30B:
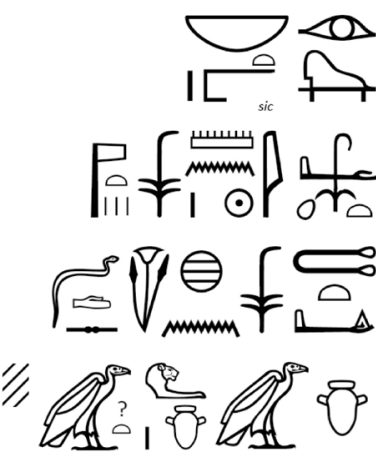
wsir nbt-pr

šm`yt imn-re nswt ntrrw

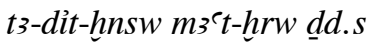

$\grave{i b}<. \grave{l} n>m w t<. \grave{l}>$ hasty $<. \grave{l} n>m w t .$.

"The Osiris Lady of the House ${ }^{\mathbf{a}},\left.\right|^{\mathbf{2}}$ Chantress of Amun-Re King of the Gods ${ }^{\mathbf{b}},\left.\right|^{\mathbf{3}}$ Tadikhonsu ${ }^{\mathbf{c}}$, justified ${ }^{\mathbf{d}}$, who says: $\left.\right|^{\mathbf{4}}$ - (My) ib-heart of (my) mother, (my) haty-heart of (my) mother ${ }^{\mathbf{e} . . . "}$

a The incipit with wsir is frequently found on Twenty-first-Twenty-second Dynasty scarabs. ${ }^{56}$ A small hollow under the $n b$-sign, retaining traces of pigment, is certainly a $t$-sign, completing $n b t$. It appears to be much shifted to the right, a feature perhaps not due to inaccuracy, for which at least one parallel exists, namely, on a heart-scarab in the Como Museum belonging to an Asetweret, sistrum-player of AmunRe, dating from the Twenty-second Dynasty. ${ }^{57}$ The $p r-s i g n$ below is the expected sign, although only the horizontal and left vertical part of the sign can be made out.

b The deceased was a Chantress, like the owner of the first scarab, but of Amun-Re, undoubtedly the most frequently occurring in the corpus collected by S. Onstine. ${ }^{58}$ The epithet of the god hints at a very probable Theban origin.

c Ranke, PN I 374, 11; II 397: examples from the Twenty-first and Twenty-second Dynasties, and the Late Period. The inverse order of signs (with the $s w$ sign in the first place) is also found among the examples listed by Ranke. The corresponding male name is attested earlier on: Ranke, PN I 110,13, Nineteenth Dynasty. The female form also occurs during the New Kingdom, es. $t 3-d y(t)-m w t$, Ranke, $P N$ I 373,14.

d The sign, similar to Gardiner M16, a lotus flower flanked by two buds, is used for writing the epithet "justified, true of voice" (Wb II 17, 16-18) for men during the Eighteenth Dynasty and especially women afterwards. ${ }^{59}$

e The reading of the last sign is not easy. In any case, we recognize here a very shortened beginning of $\mathrm{BD}$ Ch. 30B, with no suffix pronouns and without the repetition of $i b . i \mathrm{n}$ mwt. $i$; cf. above.

\subsection{Date}

This scarab shows the single-line sutures which are characteristic for the Third Intermediate Period, Twenty-first - Twenty-second Dynasty, also with that small triangle where they meet; ${ }^{60}$ many examples, a high number of which belong to temple personnel such as Chantresses or $w^{\top} b$-Priests, share many features with this scarab, both stylistic features and peculiarities in the layout and selected parts of the incised text: usually, a very limited number of lines of Chapter 30B, the preamble with wsir and the absence of the sign of the seated figure after the name of the owner. ${ }^{61}$

All these features suggest as very likely a date to the early Third Intermediate Period, Twenty-first - Twenty-second Dynasty; on the base of the only comparison found for that very peculiar "shifting” of the $t$-sign in $n b t$-pr, a date to the latter dynasty seems more likely, so ca. $950-800$ B.C. The provenance is most likely Thebes.

\section{Appendix}

\subsection{The discovery of the Palermo scarab}

The scarab was reported to have been discovered on the rock after which the city of Cefalù was probably named, no more than a few months before March 1940, by Andrea Calderazzo, then a young high school student. This information and any other news and records are due to the late Prof. Rosario Ilardo, with whom Rosati got in touch at the end of 2018; he had succeeded in finding Calderazzo, then living in Piombino (Livorno), in 2004. Unfortunately, Calderazzo was not able then to recover his own records and could rely only on his memory. However, the letter he wrote to Rosario Ilardo on May $5^{\text {th }}$, 2004, is quite informative, despite the fact that he could not remember exactly when he had found the scarab, although he was certain it was in 1939 or $1940 .^{62}$ Since direct news of such findings are rare, it is worth dwell briefly on the matter.

In that letter, Andrea Calderazzo wrote that in his teenage years he used to explore the Cefalù rock together with some schoolmates in search of small ancient objects:

In una di queste occasioni, dopo alcuni giorni di pioggia, (...) percorrendo ciascuno [scil. dei 
compagni] uno dei rivoli che scorrevano a valle dalla parte delle mura, al di sotto del Tempio di Diana, la mia attenzione fu attratta da un dischetto, grande come una moneta, di colore verde scuro. ${ }^{63}$

It took some days to remove the incrustations from the object, but at the end the surprise was great. The news spread rapidly through the school. Giuseppe Li Vecchi, a teacher of history and philosophy and honorary inspector of the Italian antiquities service (Soprintendenza archeologica), examined the object and wrote an article on its discovery for the Giornale d'Italia. $^{64}$

The scarab was left with the young boy's father for safekeeping, who was subsequently asked to turn it over to the National Museum at Palermo. After a few months, the Minister of National Education Giuseppe Bottai granted him a reward of 10 liras, but he rejected it as incommensurate to the historical and artistic value of the object. A similar low estimate was made by Giulio Farina, the Director of the Egyptian Museum in Turin. Among the records collected by Rosario Ilardo is a copy of a confidential letter to Giuseppe Li Vecchi, signed by Jole Bovio Marconi, archaeological Superintendent for Western Sicily. She writes:

\section{"Lo scarabeo è autentico egizio, ma pare valga poco! L'egittologo prof. Farina dice che simili scarabei valgono da cinque a dieci lire; però, non sa di che materia precisamente sia lavorato." ${ }^{65}$}

Certainly, Farina could not examine the scarab in person, and there were perhaps misunderstandings during the exchange of information. That letter bears the date of March $13^{\text {th }}, 1940$, and it is clear that the scarab was not yet in Palermo, but the Superintendent was expecting it.

The object was discovered, as its finder wrote in the letter, in an open area, on the ground surface, where it had probably been washed down. Thus, any different or indefinite or generic provenances that have been stated and repeated elsewhere should not be retained. Bacchi (n. 2) wrote "Castello Diana presso Cefalù", ${ }^{66}$ as if it were in the outskirts of Cefalù, but the "castle" (Castello, which is also a general and popular name for the rock itself) is properly on top of the rock, dates from the $12^{\text {th }}-13^{\text {th }}$ century and has nothing to do with Diana, whose name is on the contrary associated with a so-called Temple of Diana (see below).

Another reported provenance is "a cave of the rock": ${ }^{67}$ the finder admits in his letter that the numerous caves there were also sometime chosen for their explorations, but that was not the case when the scarab was found. The fact that this provenance is indicated by Bovio Marconi, so often in touch with the finder's family, has however to be remarked. ${ }^{68}$ The only archaeological context mentioned by the finder, though to specify only that the scarab was "below" it (meaning of course that it was at a lower level on the slope of the rock, but on the same side, the western one), was the so-called Temple of Diana (Tempio di Diana), a popular and odd name for a megalithic building probably from the $5^{\text {th }}-4^{\text {th }}$ cent. $\mathrm{BC}$, restored in the $2^{\text {nd }}($ ?) cent. $\mathrm{BC}$, which perhaps retained a function as a place of worship over the centuries (a cult of water? It is only a few meters away from a more ancient cistern), as well as a defensive function. ${ }^{69}$ The temple and the cistern are the only properly archaeological remains on the rock prior to the Byzantine age.

It cannot be excluded that the scarab was originally there, but neither can it be proved. Nowadays the area in front of the Temple of Diana is quite flat or only gently sloping, then it descends a little more steeply towards the medieval walls and is covered by grass and pine trees: on the contrary, until at least the Sixties of the last century the ground was completely treeless, as evidenced by old photos, and reforestation was actually decided in 1965 . Rather close to the Temple, a settlement was built in the Byzantine period (whose warehouses and ovens are extant), and a church dedicated to St. Anne; the Temple itself became a church for St. Venera: therefore, the area has been frequented and occupied for a long period and is not absolutely undisturbed.

So, we can indicate as the provenance of the scarab only the Cefalù rock, not far away but at a lower level than the so-called Temple of Diana.

An investigation into why the scarab arrived there, brought by whom and when, is beyond the scope of this article. Since the discovery was not from a reg- 
ular excavation and apparently fortuitous, the only possible hypothesis is perhaps that of commercial relations with the Punic world, whose presence in Cefalù has been confirmed at least since the Hellenistic age by excavations in the Graeco-Roman necropolis. ${ }^{70}$ This opinion has already been expressed by Bacchi and Bovio Marconi, ${ }^{71}$ while Sfameni Gasparro refers more generally to a context of cultural and commercial exchanges during various eras and through different agents. ${ }^{72}$

It is worth mentioning that heart-scarabs have very rarely been found in archaeological sites outside of Egypt or Nubia, only five specimens to date, according to data gathered by $\mathrm{Cl}$. Laroche: in addition to the two in Italy (one of which, Turin Suppl. 17133, entered the museum in 1853, coming from Tharros, as said above), a third one was excavated at Tell Jerisheh/Gerisa in Palestine in $1934,{ }^{73}$ and two come from Cyprus, now at the British Museum as a gift by Robert Hamilton Lang in 1913. The latter two, however, EA 51856 and 51857, were more likely purchased in Cyprus, not excavated by Hamilton Lang himself, because no precise provenance is indicated. ${ }^{74}$

Therefore, one specimen only comes from a "real" archaeological context, at Gerisa, a short distance north of Jaffa on the Yarkon river: its context is described as a level that was completely destroyed by a violent conflagration, "sealed", as it were, without architectural remains and datable to the Late Bronze Age; however, "as the excavation was made at the end of the tell, it is possible that this place served as a dump for the pottery fragments of various periods". ${ }^{75}$ Here were found scarabs of different periods, faience amulets, a Babylonian cylinder seal, bronze objects, and "Philistine" and Cypriote pottery. As such, this context is not very indicative. It should also be noted that the place lies in an area where Egyptian strongholds have been identified and the presence of Egyptians was likely. ${ }^{76}$

\subsection{Provenance of the Mandralisca scarab}

The second "Sicilian" heart-scarab certainly belonged to the Baron of Mandralisca, as we have seen above, but nothing is recorded about its provenance: the Baron could have bought it, ${ }^{77}$ or received it as a gift. It is less likely that it could come from excavations, even at Cefalù itself, like many of the archaeological finds in the Mandralisca collection; ${ }^{78}$ or Lipari, where the Baron carried out excavations at Contrada Diana. ${ }^{79}$ Although his notebooks are no longer available and in contemporary archaeological reports there is no mention of other finds of Egyptian objects there, such as shabtis, the important finds from Lipari, presently in the Mandralisca $\mathrm{Mu}-$ seum and in the Ashmolean Museum, Oxford, have been studied by several scholars ${ }^{80}$ and dated to a phase very close to the Cnidian foundation of Lipari. None of these scholars, however, have regarded the Tadikhonsu scarab as coming from this context.

\footnotetext{
Notes

${ }^{1}$ For their kind assistance and for authorization to use photographs, both authors wish to thank Francesca Spatafora, formerly Director of the Palermo Archaeological Museum, Caterina Greco, her successor, and their colleague Elena Pezzini; Augusto Purpura, President of the Fondazione Mandralisca, Vincenzo Cirincione, Secretary, and Maestro Sandro Varzi, at Cefalù; Olivia Zorn, Assistant Director, and Jana Helmbold-Doyé, Keeper of the Ägyptisches Museum und Papyrussammlung, Staatliche Museen zu Berlin; and M. Carmen Pérez Die, Chief Keeper of the Egyptian and Near Orient Antiquity Department of the Museo Arqueológico Nacional, Madrid.

${ }^{2}$ De Putter and Karlshausen, Les pierres, 1992, pp. 116-18.

${ }^{3}$ See the Appendix at the end for the surviving documentation on the discovery and the archaeological context.
}

${ }^{4}$ Bacchi, RSO 20 (1942), pp. 226-27, no photo of the second scarab. Its text translated in Malaise, Scarabées de cour, 1978, p. 53.

${ }^{5}$ Laroche, EAO 85 (2017), p. 31 (figure updated 2020).

${ }^{6}$ Suppl. 17133, studied by Bacchi, RSO 20 (1942), pp. 211-25; she did not remark their similarity. ${ }^{7}$ Curto, Storia del Museo Egizio, 199033, pp. 96 and 113; purchased in 1853 from Nicolò Musso along with other objects with the same provenance.

${ }^{8}$ Chappaz, Tiradritti, and Vandenbeusch (eds.), Akhénaton et Néfertiti, 2008, p. 269 no. 211: the text here is an offering formula, not the usual Ch. BD 30B. Cf. Milan E.1984.04.01, recently in Ceruti, Provenzali (eds.), Sotto il cielo, 2020, pp. 208-09 (late Eighteenth Dynasty); Israel Museum 76.018.0271, anonymous, attributed however to $7^{\text {th }}-5^{\text {th }}$ century B.C. in the Museum website (imj.org.il), to the Late Period by Ben-Tor, Lo scarabeo, 2005, p. 108.

${ }^{9}$ Bruxelles E 8064, Malaise, Scarabées de cœur, 1978, 
p. 86 and pl. 8; Sennefer's scarab, ibid., pl. 1.

${ }^{10}$ Acc. Nr. 86.226.22, vd. brooklynmuseum.org/ opencollection/objects/4246.

${ }^{11}$ Laroche, EAO 85 (2017).

${ }^{12}$ Feucht, Pektorale nichtköniglicher Personen, 1971, no. 91B, p. 86, Pl. XIII (Hermitage Museum; New Kingdom?). There is another heart-scarab, a bit smaller, that shows at the top of the base a sun disk flanked by cobras (?): MET 20.3.191, vd. https://www. metmuseum.org/art/collection/search/558319.

${ }^{13}$ In rare instances, the traditional Ch. 30B inscribed on scarabs bears the title: $r 3 n i b n$ wsir $\mathrm{N}$, "Spell of the heart of the Osiris N”, e.g., BM EA24767: britishmuseum.org/collection/object/Y_EA24767, in this case written at the end of the text.

${ }^{14}$ Malaise, Scarabées de cour, 1978, p. 50 with n. 6, with references dating from the New Kingdom and the Twenty-second Dynasty.

${ }^{15}$ On three out of the five King's scarabs, Carter's nos. 256a, 256q, 261m: Beinlich and Saleh, Corpus, 1989, resp. pp. 82-3, 88-9, 94-5.

${ }^{16} \mathrm{~A}$ very different interpretation of this initial part has been proposed, suggesting that $m w t$ may be instead the balance weight (Wb II 55, 3): Gee, JSSEA 36 (2009). This hypothesis, however, remains moot: one may cite similar expressions where $m w t$ is unequivocally “mother”, e.g., CT Spell 20 (CT I 56, es. B1P, B6C): “I gave you your $i b$-heart of your mother, your histy-heart of your body".

${ }^{17}$ Bacchi, RSO 20 (1942), p. 227: prj <jr> br, "uscito fuori (sottinteso: dal ventre di lei)”. Cf. Wb I 461, 5, also written $b r w$; $W b$ I 519, 16.

${ }^{18}$ Malaise, Scarabées de cour, 1978, p. 53.

${ }^{19}$ Spiegelberg, ZÄS 66 (1931); Žabkar, JNES 24 (1965), pp. 84-85; Buzov, in Amenta et al. (eds.), L'acqua nell'antico Egitto, 2005. Cf. also the variants of the Psychostasy scene where the deceased is weighed against his/her own heart: remarked already by Seeber, Totengericht, 1976, pp. 74-75; Hornung, Totenbuch, 1979, pp. 434-35; now fully examined by Gaber, in Goyon and Cardin (eds.), Proceedings Ninth ICE, 2007; Gaber, RdE 60 (2009). On the "personification" of the heart, as borne out by human headed heart-scarabs: Quirke, JEOL 37 (2001-2002); Lorand, CdE 83 (2008). Cf. also heart amulets with human heads: Sousa, Heart of Wisdom, 2011, pp. 21-27; Dolinska, in Debowska-Ludwin et al. (eds.), Aegyptus est imago caeli, 2014, pp. 217-20.

${ }^{20}$ RSO 20 (1942), p. 227: "Sia fatta elevare dalla tomba".

${ }^{21}$ Examples of New Kingdom date in Faulkner, $C D$, p. 115.

${ }^{22}$ Laroche, “Scarabées inscrits”, 2014, vol. I, pp. 568, 573.

${ }^{23}$ Catalogue des signes hiéroglyphiques, $1873^{2}$, no. 2914 to 2921.

${ }^{24}$ BM EA 64378 (Taylor, in Taylor [ed.] Journey Through the Afterlife, 2010, p. 226, no. 113; Quirke, JEOL 37 [2001-2002], p. 31) and Coll. Sofer, London (Lorand, CdE 83 [2008], p. 29), both characterized by the "mutilation" of bird-signs, cf. Miniaci, RdE 61 (2010).

${ }^{25}$ Unless it is atop a rather triangular head, now in part abraded.

${ }^{26}$ Onstine, Role of the Chantress, 2005 (the original PhD dissertation, submitted in 2001 at the University of Toronto, is available online at: https://tspace.library. utoronto.ca/bitstream/1807/15398/1/NQ58632.pdf).

${ }^{27}$ Onstine, Role of the Chantress, pp. 27-31. Ten entries only are dated to periods after the Twenty-second Dynasty.

${ }^{28}$ Onstine, Role of the Chantress, p. 27.

${ }^{29}$ Onstine, Role of the Chantress, pp. 99-140, chart 7: Reference List.

${ }^{30}$ Fragmentary stela from the sacred animal necropolis at North Saqqara: Martin, Hetepka, 1979, p. 42 no. 130 and pl. 38 .

${ }^{31}$ E.g., Taylor, in Taylor (ed.), Journey Through the Afterlife, 2010, p. 212; Faulkner, Book of the Dead, 1985, pp. 27-28. In the Eighteenth and Nineteenth Dynasties, in papyri and tombs, the Psychostasy scene is indeed the vignette for $\mathrm{BD}$ Ch. 30B, before it becomes characteristic for BD 125: Seeber, Totengericht, 1976, p. 76; Gaber, RdE 60 (2009); Quirke, Going Out in Daylight, 2013, pp. 99-100.

32 Seeber, Totengericht, 1976, pp. 95-96.

${ }^{33}$ Coffin box of Khonsumes, Inv. 253/1; no. 53 in Maspero, RecTrav 36 (1914), pp. 134-35, text on the exterior of the box, "panneau de droite, vers les pieds". Part of the scene in [Meeks, Piérini], La collection égyptienne, 1995, p. 36.

${ }^{34}$ Missing in Maspero's text.

${ }^{35}$ Maspero is reading perhaps: ...n $t 3<m>$ ib.f pr $m$... etc.; a possibly preferable alternative is: $i b . f \operatorname{pr}(. w) m$...

36 "The imy-hnt-priest in the embalming-house", cf. $L G G$ VIII, p. 103, S.2, U.1.

${ }^{37}$ Kaplony had planned to study it, cf. Kaplony, Siegel und Skarabäen, 2016; the cast of this heart-scarab is shown on pl. 106, no. 2002.

${ }^{38}$ Laroche, “Scarabées inscrits”, 2014, ch. VII.

${ }^{39}$ Malaise, Les scarabées de cour, 1978, p. 25.

${ }^{40}$ Sethe, Geschichte der Einbalsamierung, 1934, p. 11*, K.

${ }^{41}$ Yoyotte, BIFAO 54 (1954), pp. 103-04; Davoli, Saft el-Henna, 2001, pp. 99-100; Al-Abedine, CCE (S) 21 (2016).

${ }^{42}$ Edfou I/3, p. 335.

${ }^{43}$ Montet, Géographie I, pp. 210-11; Davoli, Saft el-Henna, 2001, pp. 69-70; Virenque, CRIPEL 27 (2008), pp. 144-47.

${ }^{44}$ Same wording on a statue dated to the Twentysecond Dynasty, reported to have been bought at Tell Basta: Daressy, Statues de divinités, I, pp. 302-3, CG 39217; Jansen-Winkeln, Ägyptische Biographien, 1985, I, p. 303. Same date for the inscriptions of Cairo JE 46600, a New Kingdom statue group from Saft el-Henna, usurped and dedicated to Senwaset and his wife by their son: Daressy, ASAE 20 (1920); Davoli, Saft el-Henna, 2001, pp. 35-36; Virenque, CRIPEL 27 (2008), p. 144 n. 21 (original group dated to the time of Amenhotep III: Eaton-Krauss, BES 19 [2015]).

${ }^{45} \mathrm{~Wb}$ IV 299. Under the jackal, a sign looking like an $n$ is in place of the small shrine or other support for the God's image, sometimes a 3 -sign (Gardiner N16-17).

${ }^{46}$ Formerly CG 535, now in Jerusalem, Israel Museum No. 67.30.426: Giveon, JARCE 12 (1975).

${ }^{47}$ Names formed like this are mainly for men, cf. the examples quoted above from Ranke, $P N$. 
${ }^{48}$ Should it be one sign only, it is similar, although not identical, to a $h m$-sign, U36 (cf. in the line above), or to a $s 3, \mathrm{~V} 17$.

${ }^{49} \mathrm{Cf}$., tentatively, the appearance of $i b$, heart, + stroke as a single sign in the third line of the inscription of the scarab Lot 106 in the Bonhams auction on 25.04.2012, attributed to the late New Kingdom/Third Intermediate Period: bonhams.com/auctions/19961/ lot/106/. There is something similar on Kehshasha's scarab, see below, Fig. 4.

${ }^{50}$ Laroche, "Scarabées inscrits", 2014, ch. VII; Laroche, EAO 85 (2017), figs. 3, 5, 6.

${ }^{51}$ Colin, Les Libyens, 1996, I, pp. 96ff.; Jansen-Winkeln, Orientalia 75 (2006); Pérez Die, in Broekman et al. (eds.), The Libyan Period, 2009.

${ }^{52}$ Pérez Die and Vernus, Excavaciones en Ehnasya el Medina, 1992, p. 69 doc. 46 fig. 26: the owner's name, clearly not an Egyptian one, is said to be of possibly Libyan origin; Pons Mellado, Collección egipcia, 1998, inv. no. 1981/1/102, p. 69.

${ }^{53}$ Acc. Nr. 86.226.22, brooklynmuseum.org/ opencollection/objects/4246.

${ }^{54}$ It is featured in the inventory of the Mandralisca collections drawn up by Antonino Salinas in 1888 (information courtesy of Sandro Varzi, Cefalù), and hence certainly belonged to the Baron. See the Appendix at the end for a few notes about its provenance.

${ }^{55}$ Cf. Malaise, Scarabées de cour, 1978, p. 50 and p. 82 no. 4.

${ }^{56}$ E.g. Malaise, Scarabées de cœur, 1978, p. 83 and pl. 9 (Bruxelles E.4232); also Petrie, Scarabs, 1917, pl. XLVII, 3, belonging to another $\breve{s} m^{\prime} y t$, to be added to Onstine's corpus (above, nn. 26-27); Glasgow Museum 189665(2), belonging to Nespaherentahat (Weightman and Thomson, GM 249 [2016]); Florence Egyptian Museum inv. 1179 , belonging to Ankhefenkhonsu (Guidotti [ed.], La vita oltre la morte, 2013, p. 18 no. 12); Louvre N 2853 and E 3082, resp. for Djediset and Djeddjehutyiuesankh (Gombert-Meurice, Payraudeau [eds.], Servir les dieux, 2018, p. 95, Cat. 40b, 40c: both with the title šm (yt $n$ imn).

${ }^{57}$ Inv. no. ED 893: Guidotti and Leospo, Collezione egizia, 1994, p. 70, L1, pl. 12, 29 (the owner was an ihyt n imn$r$ ). Cf. also Ballerini, Bessarione 7 (1910), p. 219: the scarab was found in situ on the chest of the mummy, under her cartonnage case (inv. ED 1).

${ }^{58}$ Onstine, Role of the Chantress, pp. 29-31; during the Third Intermediate Period, only five women in her corpus of 252 did not serve Amun.

${ }^{59}$ Geßler-Löhr, GM 116 (1990).

${ }^{60}$ Laroche, EAO 85 (2017), p. 30; for both these characteristics, cf. Turin Museum C. 5999; Durham Oriental Museum EG1833; Leiden CI 209. Cf. also, for the single-line sutura, Darmstadt HLMD-A-2006-148 (Ägyptische Mumien, 2007, p. 146 no. 136); Hildesheim 1246 (Germer et al., Mummies, 1997, pp. 24-25).

${ }^{61}$ Laroche, "Scarabées inscrits”, 2014, ch. VII ; Laroche, EAO 85 (2017), p. 30; in a few instances, also a somewhat rough workmanship. For parallels, see notes $56,57,60$.

${ }^{62}$ Ilardo touched briefly upon some of the information he had gathered in his L'eccelsa rupe. Studi, ricerche e nuove prospettive storiche sulla rocca di Cefalù, Palermo 2013, p. 227. Calderazzo passed away in 2008. It is preferable to keep here the official version of a fortuitous find; however, it seems, from the statements of the finder himself, that "explorations" of the rock were at least repeated, by several people and with a specific purpose, not only to take a walk.

63 "On one of these occasions, after it had been raining for a few days, (...) each one [scil. of the schoolmates] walking along one of the rivulets that ran downhill from the walls, below the Temple of Diana, my attention was drawn to a disk, as large as a coin, dark green in color".

${ }^{64}$ We were unable to determine in which issue of this popular daily newspaper the article appeared.

65 "The scarab is an authentic Egyptian object, but apparently it is worth little! The Egyptologist Prof. Farina says that such scarabs may be worth fiveten liras. However, he does not know exactly what material it is made of". Although the words are clear, what is meant is perhaps not the market value but the reward up to a maximum of a quarter of the value granted under the provisions of Law 1089/1939 (concerning the protection of artistic and historical assets). 10 liras of the time were worth less than 9 euros, a very small sum.

${ }^{66}$ Retained in Sfameni Gasparro, I culti orientali in Sicilia, 1973, pp. 83-84, 231.

${ }^{67}$ Bovio Marconi, in Atti del VII Congresso nazionale di storia dell'architettura, 1955, p. 215.

${ }^{68}$ It cannot be excluded that the circumstances were less "peaceful" than what appears from the finder's memories: the Superintendent is certainly very annoyed in the letter, where she comments that the boy's father is ungrateful, because she could have seized the scarab for failure to report its finding. She may have been aware of other, different circumstances that can no longer be documented.

${ }^{69}$ Tullio, Kokalos 20 (1974), pp. 146-50; Van Essen, Mélanges de l'Ecole française de Rome 69 (1957); Purpura, Sicilia Archeologica 37 (1978), pp. 62-63; Tullio, in Enciclopedia dell'Arte Antica Classica e Orientale, Secondo Supplemento, 1995, p. 91.

${ }^{70}$ Tullio, in Spanò Giammellaro (ed.), Atti del V Congresso, 2005, pp. 837-39. For aegyptiaca in Western Sicily, in addition to Sfameni Gasparro, I culti orientali in Sicilia, 1973: Poma, in Famà (ed.), Museo Regionale di Trapani, 2009, and previously Verga, Sicilia Archeologica 40 (1979); Spanò Giammellaro, in Gandolfo (ed.), Pulcherrima Res, 2008; Famà, Inferrera and Militello (eds.), Magia d'Egitto, 2015; De Angelis, Archaeological Reports 53 (2006-2007) and 58 (2012); Giglio Cerniglia (ed.), Il culto di Iside, 2017; Niemeyer, in Amadasi Guzzo et al. (eds.), Da Pyrgi a Mozia, 2002; Schön and Töpfer (eds.), Karthago Dialoge, 2016. On the colony of Motya, cf. Nigro and Spagnoli, Landing on Motya, 2017. Cf. also: https://www.arcait. it/bibliografia/sicelioti-fenici-punici-siculi-sicanielimi-2006-1850/.

${ }^{71}$ Above, nn. 4 and 67.

72 Sfameni Gasparro, I culti orientali in Sicilia, 1973, pp. 83-84, 231-32. 
${ }^{73}$ Rockefeller Archaeological Museum, Jerusalem, no. 343114. The news of the first artifact of that type ever found in Palestine appeared in the Jewish Telegraph Agency of June 26, 1934. It is described in Rowe, Catalogue, 1936, pp. 152-53 no. 641, without a photo; text on twelve lines, the first two, with the name of the owner, perhaps intentionally abraded; text of BD Ch.30B, dated to the New Kingdom, probably Nineteenth Dynasty. Rowe quotes from the excavator's report that it was "associated with 'Philistine' pottery under fallen burnt-brick wall in Level III".

${ }^{74}$ Hamilton Lang acquired many antiquities there and led excavations mainly at Dhali/Idalion and Pyla. BM EA51856, unpublished: britishmuseum.org/ collection/object/Y_EA51856. Prob. Late Period; the text is not a regular BD "heart-chapter". BM EA51857, unpublished: britishmuseum.org/collection/object/Y_ EA51857: made of red jasper, dated to the New Kingdom, with the opening phrases of Ch. BD 30B for an individual named "May".

${ }^{75}$ Sukenik, QDAP 4 (1935), p. 209.

${ }^{76}$ E.g., Nigro, in CMAO VI, 1996, p. 10; Gadot, Tel Aviv 37 (2010), with references: the destruction of the Egyptian centers there can be dated approximately to the late thirteenth - early twelfth century BC. A more general overview: Ben-Tor (ed.), Pharaoh in Canaan, 2016.

${ }^{77} \mathrm{He}$ had many interests and a rich network of correspondents: e.g., Crisà, Lanx 4 (2009).

${ }^{78}$ Tullio, La collezione archeologica, 1979, pp. 14-15.

${ }^{79}$ Ingoglia, Sicilia Antiqua 4 (2007), p. 49, with references. After the Baron's death, excavations were carried out in 1878-79 by Giuseppe Scolarici in a neighboring property.

${ }^{80}$ On the important Egyptian finds there, including a small aryballos with the cartouche of Apries, see Bernabò Brea, in Spigo and Martinelli (eds.), Dieci anni al Museo Eoliano, 1996; Cultraro, in Di Natale and Basile (eds.), Atti XVIII Convegno, 2020; previously, Boardman, Greeks Overseas, 1964, p. 144.

\section{Bibliography}

Ägyptische Mumien - Unsterblichkeit im Land der Pharaonen, Stuttgart 2007.

Al-Abedine, Adel Zine, "Le titre du grand prêtre du dieu Sopdou Wn Pth", CCE (S) 21 (2016), pp. 183-90.

Bacchi, Ernesta, "Lo scarabeo del cuore di Thutmòse IV", RSO 20 (1942), pp. 211-27.

Ballerini, Francesco, "Antichità egiziane nel Museo Civico di Como”, Bessarione 7 (1910), pp. 210-37.

Beinlich, Horst and Mohammed Saleh, Corpus der hieroglyphischen Inschriften aus dem Grab des Tutanchamun: mit Konkordanz der Nummernsysteme des 'Journal d'Entrée' des Ägyptischen Museums Kairo, der Handlist to Howard Carter's catalogue of objects in Tut'ankhamun's tomb und der Ausstellungs-Nummer des Ägyptischen Museums Kairo, Oxford 1989.

Ben-Tor, Daphna, Lo scarabeo. Il segreto della vita e il confine tra $i$ mondi, Roma 2005 (Italian edition of The Scarab. A Reflection of Ancient Egypt, Jerusalem 1993).

Ben-Tor, Daphna (ed.), Pharaoh in Canaan. The Untold Story (Catalogue of the Exhibition, The Israel Museum, Winter-Fall 2016), Jerusalem 2016.
Bernabò Brea, Luigi, “Apporti egizi alla fondazione della Lipàra cnidia e sviluppo delle sue necropoli”, in: Umberto Spigo and M. Clara Martinelli (eds.), Dieci anni al Museo Eoliano (1987- 1996). Ricerche e studi (Quaderni del Museo Archeologico Regionale Eoliano 1), Messina 1996, pp. 95-101.

Boardman, John, The Greeks Overseas: Their Early Colonies and Trade, London 1964.

Bovio Marconi, Jole, "I monumenti megalitici di Cefalù e l'architettura preistorica mediterranea”, in: Atti del VII Congresso nazionale di storia dell'architettura, Palermo, 24-30 settembre 1950, Palermo 1955, pp. 213-21.

Buzov, Emil, “The Role of the Heart in the Purification”, in: Alessia Amenta, M. Michela Luiselli and Marta Novella Sordi (eds.), L'acqua nell'antico Egitto: vita, rigenerazione, incantesimo, medicamento. Proceedings of the First International Conference for Young Egyptologists (Italy, Chianciano Terme, October 15-18, 2003), Roma 2005, pp. 273-81.

Catalogue des signes hiéroglyphiques de l'Imprimerie Nationale. Deuxième édition, Paris 1873.

Ceruti, Sabrina and Anna Provenzali (eds.), Sotto il cielo di Nut. Egitto divino, Milano 2020.

Chappaz, Jean-Luc, Francesco Tiradritti and Marie Vandenbeusch (eds.), Akhénaton et Néfertiti. Soleil et ombres des pharaons (Catalogue de l'exposition, Musée d'art et d'histoire, 17 octobre 2008- $1^{\text {er }}$ février 2009), Genève 2008.

Colin, Frédéric, Les Libyens en Égypte (XVe siècle a.C-IIe siècle p.C.). Onomastique et histoire. Diss. Université Libre de Bruxelles 1996 (tel.archives-ouvertes.fr/tel00120038).

Crisà, Antonino, "Lettera di Enrico Pirajno di Mandralisca a Karl von Estorff con notizie di scavi e ricerche numismatiche a Lipari ed acquisti antiquari a Tindari”, Lanx 4 (2009), pp. 146-55.

Cultraro, Massimo, "Documenti di culti funerari di origine egizia a Lipari in età arcaica. Una nota preliminare”, in: Anna Di Natale and Corrado Basile (eds.), Atti del XVIII Convegno di Egittologia e Papirologia - Siracusa, 20-23 settembre 2018 (Quaderni del Museo del Papiro XVII), Siracusa 2020, pp. 153-74.

Curto, Silvio, Storia del Museo Egizio di Torino, Torino $1990^{3}$.

Daressy, Georges, Statues de divinitès : Nos 38001-39384 (CGC), I, Le Caire 1906.

Daressy, Georges, “Un groupe de Saft el Henneh”, ASAE 20 (1920), pp. 123-28.

Davoli, Paola, Saft el-Henna, archeologia e storia di una città del Delta orientale (Archeologia e storia della civiltà egiziana e del Vicino Oriente antico - Materiali e studi 6), Imola 2001.

De Angelis, Francesco, "Archaeology in Sicily", Archaeological Reports 53 (2006-07), pp. 123-90; 58 (2012), pp. 123-95.

De Putter, Thierry and Christina Karlshausen, Les pierres utilisées dans la sculpture et l'architecture de l'Égypte pharaonique. Guide pratique illustré (Connaissance de l’Égypte ancienne 4), Brussels 1992.

Dolinska, Monika, "Small Head, Little Mystery", in: Johanna Debowska-Ludwin, Mariusz A. Jucha and Piotr Kolodziejczyk (eds.), Aegyptus est imago caeli: 
Studies Presented to Krzysztof M. Cialowicz on his 60th Birthday, Kracow 2014, pp. 217-20.

Eaton-Krauss, Marianne, "The Original Owner of Egyptian Museum, Cairo JE 46600”, BES 19 (2015), pp. 225-36.

Edfou I/3 = Marquis de Rochemonteix and Émile Chassinat, Le temple d'Edfou, $1987^{2}$.

Famà, M. Luisa, Ivana Inferrera and Pietro Militello (eds.), Magia d'Egitto. Mostre archeologiche e congressi in Sicilia, Trapani 2015.

Feucht, Erika, Pektorale nichtköniglicher Personen (ÄA 22), Wiesbaden 1971.

Gaber, Hanane, "Les scarabées de cœur à tête humaine à la lumière d'une variante de la pesée du cœur", in: Jean-Claude Goyon and Christine Cardin (eds.), Proceedings of the Ninth International Congress of Egyptologists, Grenoble, 6-12 Septembre 2004 (OLA 150), Leuven-Paris-Dudley, MA 2007, pp. 743-48.

Gaber, Hanane, "Deux variantes de la scène de la psychostasie (chapitres 30 et 125 du Livre des Morts)", RdE 60 (2009), pp. 1-16.

Gadot, Yuval, "The Late Bronze Egyptian Estate at Aphek", Tel Aviv 37 (2010), pp. 48-66.

Gee, John, "Of Heart Scarabs and Balance Weights: A New Interpretation of Book of the Dead 30B”, JSSEA 36 (2009), pp. 1-15.

Germer, Renate, Mummies: Life After Death in Ancient Egypt, Munich-New York 1997.

Geßler-Löhr, Beatrix, "Zur Schreibung von $m_{3}{ }^{e}-h r w$ mit der Blume", GM 116 (1990), pp. 25-43.

Giglio Cerniglia, Rossella (ed.), Il culto di Iside nel Mediterraneo tra Lilibeo e Alessandria d'Egitto. Atti del Convegno, Marsala, 13-14 maggio 2011, Pisa 2017.

Giveon, Raphael, "A Late Egyptian Statue from the Eastern Delta”, JARCE 12 (1975), pp. 19-21.

Gombert-Meurice, Florence and Frédéric Payraudeau (eds.), Servir les dieux d'Égypte. Divines adoratrices, chanteuses et prêtres d'Amon à Thèbes (Catalogue de l'exposition, Musée de Grenoble, 25 octobre 2018 27 janvier 2019), Paris-Grenoble 2018.

Guidotti, M. Cristina (ed.), La vita oltre la morte. Il corredo funerario nell'antico Egitto, Ospedaletto (Pisa) 2013.

Guidotti, M. Cristina and Enrichetta Leospo, La collezione egizia del Civico Museo Archeologico di Como, Como 1994.

Hornung, Erik, Das Totenbuch der Ägypter, Zürich 1979.

Ingoglia, Caterina, "La necropoli greco-romana di Lipari: storia degli scavi e prospettive di ricerca”, Sicilia Antiqua 4 (2007), pp. 49-64.

Jansen-Winkeln, Karl, Ägyptische Biographien der 22. und 23. Dynastie, Teil I: Übersetzung und Kommentar (̈̈AT 8/1), Wiesbaden 1985.

Jansen-Winkeln, Karl, “Die Libyer in Herakleopolis Magna”, Orientalia 75 (2006), pp. 297-316.

Kaplony, Peter A., Siegel und Skarabäen in der Sammlung Georges Michaelides. Ägyptisches Museum und Papyrussammlung der Staatlichen Museen zu Berlin. Tafeln und Manuskript (Michael E. Habicht, Renate Siegmann eds.), Berlin 2016.

Laroche, Claude, "Les scarabées inscrits et autres amulettes de cœur de l'Égypte ancienne (présentation, corpus, critères de datation, caractéristiques, collections)", PhD dissertation, Paris IV - Sorbonne, 06.12.2014 (theses.fr/2014PA040240), publication forthcoming.

Laroche, Claude, "Les scarabées inscrits et autres amulettes de cœur de l'Égypte ancienne”, EAO 85 (2017), pp. 21-34.

LGG = Leitz, Christian (ed.), Lexikon der ägyptischen Götter und Götterbezeichnungen, 8 vols. (OLA 110-116, 129), Leuven-Paris-Dudley, MA, 2002-2003.

Lorand, David, "Quatre scarabées de cœur inscrits à tête humaine”, CdE 83 (2008), pp. 20-40.

Malaise, Michel, Les scarabées de cœur dans l'Égypte ancienne: avec un appendice sur les scarabées de cour des Musées Royaux d'Art et d'Histoire de Bruxelles (MRE 4), Bruxelles 1978.

Martin, Geoffrey Thorndike, The Tomb of Hetepka and Other Reliefs and Inscriptions from the Sacred Animal Necropolis, North Saqqâra 1964-1973, London 1979.

Maspero, Gaston, “Les monuments égyptiens du Musée de Marseille”, RecTrav 36 (1914), pp. 128- 45.

[Meeks, Christine and Dimitri, and Gisèle Piérini], La collection égyptienne: guide du visiteur (Cahier du Musée d’archéologie méditerranéenne), Marseille $1995^{2}$.

Miniaci, Gianluca, “The Incomplete Hieroglyphs System at the End of the Middle Kingdom", RdE 61 (2010), pp. 113-34.

Niemeyer, Hans Georg, “Aegyptiaca im Mittelmeerraum: Handelsgut der Phönizier? Zur Beschreibung eines Problems in der archäologischen Forschung", in: M. Giulia Amadasi Guzzo, Mario Liverani and Paolo Matthiae (eds.), Da Pyrgi a Mozia. Studi sull'archeologia del Mediterraneo in memoria di Antonia Ciasca, Roma 2002, pp. 367-72.

Nigro, Lorenzo, "Le residenze palestinesi del Bronzo Tardo - I modelli planimetrici e strutturali”, in: Contributi e Materiali di Archeologia Orientale VI, Roma 1996, pp. 1-69.

Nigro, Lorenzo and Francesca Spagnoli, Landing on Motya. The Earliest Phoenician Settlement of the $8^{\text {th }}$ Century $B C$ and the Creation of a West-Phoenician Cultural Identity in the Excavations of the Sapienza University of Rome - 2012-2016, Roma 2017.

Onstine, Suzanne Lynn, The Role of the Chantress ( $\breve{S} m$ 'yt) in Ancient Egypt (BAR Int. Series 1401), Oxford 2005.

Pérez Die, Maria del Carmen, “The Third Intermediate Period Necropolis at Herakleopolis Magna”, in: Gerard P.F. Broekman, Robert J. Demarée and Olaf E. Kaper (eds.), The Libyan Period in Egypt. Historical and Cultural Studies into the $21^{\text {st }}-24^{\text {th }}$ Dynasties: Proceedings of a Conference at Leiden University, 25-27 October 2007, Leiden 2009, pp. 303-26.

Pérez Die, Maria del Carmen and Pascal Vernus, Excavaciones en Ehnasya el Medina (Heracleópolis Magna): introducción general, inscripciones (Informes arqueológicos, Egipto 1), Madrid 1992.

Petrie, William Matthew Flinders, Scarabs and Cylinders with Names (BSAE, London 1917), reprint London 1974.

Poma, Luana, "Amuleti, scarabei e statuette ushabti", in: M. Luisa Famà (ed.), Il Museo Regionale "A. Pepoli” di Trapani. Le collezioni archeologiche, Bari 2009, pp. 285-96. 
Pons Mellado, Esther (ed.), La colección egipcia de la Real Academia de Córdoba, Córdoba 1998.

Purpura, Gianfranco, "Le cave di pietra della rocca di Cefalù”, Sicilia Archeologica 37 (1978), pp. 59-67.

Quirke, Stephen, “Two Thirteenth Dynasty HeartScarabs", JEOL 37 (2001-2002), pp. 31-40.

Quirke, Stephen, Going Out in Daylight - prt $m$ hrw: The Ancient Egyptian Book of the Dead. Translation, Sources, Meanings (GHP Egyptology 20), London 2013.

Rowe, Alan, A Catalogue of Egyptian Scarabs, Scaraboids, Seals and Amulets in the Palestine Archaeological Museum, Le Caire 1936.

Sagrillo, Troy L., "The Heart Scarab of King Shoshenq III (Brooklyn Museum 61.10)”, JEA 97 (2011), pp. 240-46.

Schön, Frerich and Hanni Töpfer (eds.), Karthago Dialoge. Karthago und der punische Mittelmeerraum Kulturkontakte und Kulturtransfers im 1. Jahrtausend $v$. Chr., Tübingen 2016.

Schumacher, Inke W., Der Gott Sopdu, der Herr der Fremdländer (OBO 79), Freiburg-Göttingen 1988.

Seeber, Christine, Untersuchungen zur Darstellung des Totengerichts im Alten Ägypten (MÄS 35), Berlin 1976.

Sethe, Kurt, "Zur Geschichte der Einbalsamierung bei den Ägyptern und einiger damit verbundener Bräuche”, SPAW 1934, pp. 211-39.

Sfameni Gasparro, Giulia, I culti orientali in Sicilia (EPRO 31), Leiden 1973.

Sousa, Rogério, The Heart of Wisdom: Studies on the Heart Amulet in Ancient Egypt (BAR Int. Series 2211), Oxford 2011.

Spanò Giammellaro, Antonella, "I manufatti egiziani ed egittizzanti”, in: Lucina Gandolfo (ed.), Pulcherrima Res: Preziosi ornamenti dal passato, Palermo 2008, pp. 63-85.

Spiegelberg, Wilhelm, “Das Herz als zweites Wesen des Menschen”, ZÄS 66 (1931), pp. 35-37.
Sukenik, Eleazar Lipa, "Excavations in Palestine 1933-34

- Tell el Jeri' ${ }^{-}$she", Quarterly of the Department of Antiquities in Palestine 4 (1935), pp. 208-09.

Taylor, John H., “Judgement”, in: John H. Taylor (ed.), Journey Through the Afterlife. Ancient Egyptian Book of the Dead, London 2010, pp. 204-37.

Tullio, Amedeo, "Saggio sulla topografia e sulle antichità di Cefalù”, Kokalos 20 (1974), pp. 119- 51.

Tullio, Amedeo, La collezione archeologica del Museo Mandralisca, Cefalù 1979.

Tullio, Amedeo, “Cefalù”, in: Enciclopedia dell'Arte Antica Classica e Orientale, Secondo Supplemento 1971-1994, II, Roma 1995, pp. 90-93.

Tullio, Amedeo, "Presenze puniche nella necropoli ellenistico-romana di Cefalù”, in: Antonella Spanò Giammellaro (ed.), Atti del V Congresso Internazionale di Studi Fenici e Punici- Marsala- Palermo, 2-8 ottobre 2000, II, Palermo 2005, pp. 837-48.

Van Essen, Charles-Claude, "La date du sanctuaire mégalithique de Cefalù”, Mélanges de l'École française de Rome 69 (1957), pp. 45-48.

Verga, Silvana, “Scarabei e scaraboidi nel Museo Nazionale Pepoli di Trapani”, Sicilia Archeologica 40 (1979), pp. 27-36.

Virenque, Hélène, “Saft el-Henneh aux époques tardives: remarques sur la métropole et les sanctuaires de la XX province de Basse Égypte”, CRIPEL 27 (2008), pp. 141-50.

Weightman, Brian and James K. Thompson, “The Heart Scarab of Nespaherentahat”, GM 249 (2016), pp. 165-69.

Yoyotte, Jean, "Prêtres et sanctuaires du nome héliopolite à la Basse Époque”, BIFAO 54 (1954), pp. 83-115.

Žabkar, Louis V., "Some Observations on T.G. Allen's Edition of the Book of the Dead", JNES 24 (1965), pp. 75-87. 